\title{
Complementarity and Coalescence: Dante and the Sociology of Authentic Being
}

\author{
S’io era corpo, e qui non si concepe \\ com' una dimensione altro patio, \\ ch'esser convien se corpo in corpo repe, \\ accender ne dovria più il disio \\ di veder quella essenza in che si vede \\ come nostra natura e Dio s'unio.
}

(Par. II.37-42) ${ }^{1}$

1. Introduction: the social dimension of the Inferno and a moment of misgiving. 2. The New Testament perspective: Pauline and Johannine collectivity. 3. The sociology of estrangement: self-denial and social denial. 4. The sociology of emergence: co-presence, co-immanence and the revised dimensionality of being.

Kenelm Foster, not far into his preliminary meditation on the theology of the Inferno, has this to say about its social aspect, its sense of sin as civic:

In fact, there is generally a very human quality about the Inferno, not unconnected, I think, with the strong social and political emphasis that has often been remarked in it. Most of the damned have violated human nature in some way, in themselves or in their fellow men; and the deeper damnations are reserved for the sinners against their fellows. In the circles of 'frode' - if one excepts Satan himself - all the sins punished are sins against one's neighbour. I fancy that Ezra Pound said somewhere that the damned in the lower circles of Inferno were all 'damned for money'. This, if he said it, was an exaggeration, but certainly the lower circles of Malebolge and Cocito are malevolently anti-social, although this aspect is not everywhere stressed by the poet, and in one case - Canto XIX - the society in question is 'supernatural'

\footnotetext{
${ }^{1}$ If I was body (and here we conceive not how one bulk could brook another, which must be if body enters body), the more should longing enkindle us to see that essence wherein we behold how our nature and God united themselves. I am grateful to the President and staff of the John Cabot American University in Rome where, by their kind invitation, this paper was first delivered.
} 
- the Church. The phrase Charles Williams applied to Geryon, the symbol of Deceit, might indeed be applied to all that lower Hell into which Geryon carried Dante (canto XVII): it is 'the City infernalized'.'

This, as far as it goes, is unexceptionable, many and possibly most of the sins punished in hell having about them the nature of injury, of doing down the next man. But for all that, there is a sense in the Inferno in which every dysfunctionality on the surface of things, including every specifically social dysfunctionality, is reducible to dysfunctionality in the depths, to the kind of dysfunctionality whereby, having established himself at the centre of his own universe, the individual cannot but live in a state of resentment with regard to the next man, with regard, that is to say, to all those who have similarly established themselves at the centre of their universe. Strictly speaking, therefore, the social emphases of the Inferno, prominent as they are in the text and decisive for its overall interpretation, stand to be referred to something both prior and more profound than themselves, to the tragic substance of self as divided in the forum of conscience. Short of this, of a referral of dividedness in the open forum to dividedness in the innermost reaches of personality, the root cause of every instance of antagonism on the surface remains hidden from view, obscured by its mere phenomenology or showing forth. That said, however, there is no denying the social character of Dante's discourse in the Inferno and thus the possibility of seeing and setting this up as an object of enquiry in its own right, especially in that it is here, at the point of being under the aspect of collectivity, that we discover some of his most radiant emphases in the area of moral philosophy and theology.

2. In proposing the social aspect of the Commedia as an object of enquiry in its own right, we need for a moment to look back to the New Testament as a point of departure; for the New Testament, if not systematically then even so unmistakably, commends two kinds of collectivity or social configuration, the one Pauline and the other Johannine in origin. On the one hand, then, there is Paul's sense of the common life as a matter of complementarity, each individual facilitating that life by bringing to it what he or she does best, the substance of his or her genius or vocation; so, for example, as a classic instance of his anthropomorphism, of his sense of the indispensability of each member of the body of Christ to the proper operation of the whole, these lines from I Corinthians 12, an essay in functionality as a matter of $c o$-functionality, in collectivity as a matter of cooperation:

${ }^{2}$ Kenelm Foster, O.P., God’s Tree. Essays on Dante and Other Matters (London: Blackfriars, 1957), pp. 54-55. 
Vos autem estis corpus Christi et membra de membro, et quosdam quidem posuit Deus in ecclesia primum apostolos, secundo prophetas, tertio doctores, deinde virtutes exin gratias curationum, opitulationes, gubernationes, genera linguarum. Numquid omnes apostoli, numquid omnes prophetae, numquid omnes doctores, numquid omnes virtutes, numquid omnes gratiam habent curationum, numquid omnes linguis loquuntur, numquid omnes interpretantur?

(I Cor. 12:27-30) $)^{3}$

Uppermost in Paul's mind as he considers the nature and the mechanism of the common life are two things: first, the importance of the individual's seeking and living out his or her proper calling, as but part of the body of Christ; and, following on from this, the possibility of defining the relationship between one man and another in terms of the kind of proximity whereby the one is present to the other as an extrinsic principle of his well-being. Self, in other words, comes alongside and engages with the other-than-self as part of what it means to be in Christ, a notion which, though less than adequate to all this might mean for Paul, nonetheless gives satisfactory expression to one aspect of it, to how Christian neighbourliness might be usefully understood.

But there is in the New Testament a further model of the collective life, one which, while both acknowledging the Pauline model, deepens it in favour of something closer to coalescence than to contiguity as a way of developing this issue, to a sense of collectivity as involving the occupation by the many of one and the same spiritual space. Each individual, in other words, is present to his or her neighbour, not only nor even primarily as a fellow labourer, but as an inward and abiding presence, as a principle of being operative from out of the recesses of being. Fundamental here are the farewell discourses of Christ prior to his passion as recorded in the fourth gospel, discourses designed by way of a series of immanences to confirm in circumstances of faith the co-inherence both of man and God and of man and man as party to a common undertaking. First, then, and as quickened by a sense of imminent catastrophe, there is Christ's sense of his being in the Father, of the Father's being in him, and of this as the

3 Now you are Christ's body, and each of you a limb or organ of it. Within our community God has appointed, in the first place apostles, and in the second place prophets, thirdly teachers; then miracle workers, then those who have gifts of healing, or ability to help others or power to guide them, or the gift of ecstatic utterance of various kinds. Are all apostles? all prophets? all teachers? Do all work miracles? Have all gifts of healing? Do all speak in tongues of ecstasy? Can all interpret them? (REB). Eph. 4:11-12: 'Et ipse dedit quosdam quidem apostolos, quosdam autem prophetas, alios vero evangelistas, alios autem pastores et doctores ad consummationem sanctorum in opus ministerii in aedificationem corporis Christi', etc. 
basis of his messianic status; so, for example, John 10:37-38 and 14:10-11: 'Si non facio opera Patris mei, nolite credere mihi; si autem facio, et si mihi non vultis credere operibus, credite ut cognoscatis et credatis quia in me est Pater et ego in Patris ... non credis quia ego in Patre et Pater in me? Est verba quae ego loquor vobis a me ipso non loquor, Pater autem in me manens, ipse facit opera. Non creditis quia ego in Patre et Pater in me est. ${ }^{14}$ To the fore, then, in this second moment of the gospel meditation is an emphasis on the mutual indwellingness of the One who sends and of the one who is sent, this in turn determining the relationship one with another of those naming the name; for in the degree to which a man names the name he not only indwells the Christ, in turn to be indwelt by him, but he indwells all those professing the Christ, again to be indwelt by them:

Non pro his autem rogo tantum, sed pro eis qui credituri sunt per verbum eorum in me, ut omnes unum sint sicut tu, Pater, in me et ego in te ut et ipsi in nobis unum sint, ut mundus credat quia tu me misisti. Et ego claritatem quam dedisti mihi dedi eis ut sint unum sicut nos sumus, ego in eis et tu in me ut sint consummati in unum ...

$(\text { John } 17: 20-22)^{5}$

Here, therefore, in the Johannine phase of the argument, it is a question, less of complimentarity, than of co-immanence as the form of collective consciousness, of how one man might be said to enter into the humanity of another there to shape and substantiate it from deep within itself.

3. Coming now to Dante, these models of collective being, the Pauline model of contiguity and the Johannine model of co-inherence, bring us to one of the most luminous aspects of his spirituality in the Commedia, to his rejoicing in the rich configuration of man's collective life in the Spirit. Let us begin, however, if only because this is where Dante himself begins, at the opposite end, with the kinds of tension and antagonism tending to undermine and ultimately to destroy complementarity and mutual

${ }^{4}$ If I am not acting as my Father would, do not believe me. But if I am, accept the evidence of my deeds, even if you do not believe me, so that you may recognize and know that the Father is in me, and I in the Father ... Do you not believe that I am in the Father and the Father in me; I am not myself the source of the words I speak to you; it is the Father who dwells in me doing his own work. Believe me when I say that I am in the Father and the Father in me.

${ }^{5}$ But it is not for these alone that I pray, but for those also who through their words put their faith in me; may they all be one: as you, Father, are in me, and I in you, so also may they be in us, that the world may believe that you sent me. The glory which you gave me I have given to them, that they may be one as we are one; I in them and you in me, may they be perfectly one. 
immanence thus understood as models of man's being together as man. Dante's, then, with Aristotle's, is a sense of the psychosomatic structure of man's presence in the world, the rational part of his nature constituting the species intelligibilis or intelligible and operative principle of the whole. But there is a difference, for happy as he is to talk with Aristotle and the Aristotelians about human nature in terms of the specification of the whole by way of the psyche rather than of the soma, he is happier, whenever the opportunity presents itself, to proceed in affective categories, to discuss the whole thing in terms of the complexity of properly human loving. Man as man, then, loves variously: like the stones he cleaves to the ground, like the plants he seeks out the goodness of the soil and the sunlight as conditions of his proper well-being, like the animals he craves the pleasure of eating, sleeping and procreating, and like the angels he yearns for an uncluttered act of intellection, for an orderly understanding both of self and of the world beyond self; so, for example, as testimony to a uniform pattern of thought in Dante, and indeed to a uniform pattern of rejoicing, these lines from Book III of the Convivio, a hymn to the openness of being in general and of human being in particular to celebration under the aspect of its multiple affectivity:

Onde è da sapere che ciascuna cosa, come detto è di sopra, per la ragione di sopra mostrata ha 'l suo speziale amore. Come le corpora simplici hanno amore naturato in sé a lo luogo proprio, e però la terra sempre discende al centro; lo fuoco ha [amore a] la circunferenza di sopra, lungo lo cielo de la luna, e però sempre sale a quello. Le corpora composte prima, sì come sono le minere, hanno amore a lo luogo dove la loro generazione è ordinata, e in quello crescono e acquistano vigore e potenza; onde vedemo la calamita sempre da la parte de la sua generazione ricevere vertù. Le piante, che sono prima animate, hanno amore a certo luogo più manifestamente, secondo che la complessione richiede; e però vedemo certe piante lungo l'acque quasi c[ontent]arsi, e certe sopra li gioghi de le montagne, e certe ne le piagge e dappiè monti: le quali se si transmutano, o muoiono del tutto o vivono quasi triste, disgiunte dal loro amico. Li animali bruti hanno più manifesto amore non solamente a li luoghi, ma l'uno l'altro vedemo amare. $\mathrm{Li}$ uomini hanno loro proprio amore a le perfette e oneste cose. E però che l'uomo, avvegna che una sola sustanza sia, tuttavia [la] forma, per la sua nobilitade, ha in sé e la natura [d'ognuna di] queste cose, tutti questi amori puote avere e tutti li ha.

(Conv. III.iii.2-5) $)^{6}$

${ }^{6}$ It should be explained here that, as was said above, for the reason given there, every being has a love specific to it. Just as simple bodies have an inborn love for the place proper to them - so that earth always descends to the centre, while fire has an inborn love 
But if man as man loves by way of the many impulses proper to his complex nature, then how are these impulses to be organized, fitted in with one another within the economy of the whole? By way, Dante thinks, of their bringing home to the kind of love given with the act itself of existence and inclining the individual to seek out God as the beginning and end of all seeking, herein alone lying the ground and legitimacy of his every affective inflexion of the spirit. The key passages here, the first of them touching on the species of human loving precisely as such and the second of them on the gathering in of one kind of love to another, run as follows:

"Né creator né creatura mai" cominciò el, "figliuol, fu sanza amore, o naturale o d'animo; e tu 'l sai.

Lo naturale è sempre sanza errore, ma l'altro puote errar per malo obietto o per troppo o per poco di vigore.

Mentre ch'elli è nel primo ben diretto, e ne' secondi sé stesso misura, esser non può cagion di mal diletto;

ma quando al mal si torce, $\mathrm{o}$ con più cura o con men che non dee corre nel bene, contra 'l fattore adovra sua fattura.

Quinci comprender puoi ch'esser convene amor sementa in voi d'ogne virtute e d'ogne operazion che merta pene"

Però, là onde vegna lo 'ntelletto de le prime notizie, omo non sape, e de' primi appetibili l'affetto, che sono in voi sì come studio in ape di far lo mele; e questa prima voglia

for the circumference above us bordering the heaven of the Moon, and therefore always rises upwards towards that - so primary compound bodies, such as minerals, have a love for the place suited to their generation; in that place they grow, and from it they derive their vigour and power. That is why, as we observe, the magnet always receives power from the quarter in which it was generated. Plants, which are the primary form of animate life, even more clearly have a love for certain places, in accordance with what their constitution requires; so we see some deriving pleasure, as it were, when alongside water, others when on the ridges of mountains, others when on slopes and on foothills; if they are transplanted, they either die completely or live a sad life, as it were, like beings separated from their friends. Human beings have their specific love for what is perfect and just. And since the human being, despite the fact that his whole form constitutes a single substance in virtue of its nobility, has a nature that embraces all these features, he can have all these loves, and indeed does have them. 
merto di lode o di biasmo non cape.

Or perché a questa ogn' altra si raccoglia, innata v'è la virtù che consiglia, e de l'assenso de' tener la soglia.

Quest' è 'l principio là onde si piglia ragion di meritare in voi, secondo che buoni e rei amori accoglie e viglia.

Color che ragionando andaro al fondo, s'accorser d'esta innata libertate; però moralità lasciaro al mondo.

(Purg. XVII. 91-102 and XVIII.55-69) ${ }^{7}$

7 He began: "Neither creator nor creature, my son, was ever without love, either natural or of the mind, and this you know. The natural is always without error; but the other may err either through an evil object, or through too much or too little vigour. While it is directed on the primal good, and on secondary goods observes right measure, it cannot be the cause of sinful pleasure. But when it turns awry to evil, or speeds to good with more zeal, or with less, than it ought, against the creator works his creature. Hence you can comprehend that love must needs be the seed in you of every virtue and of every action deserving punishment ... Therefore, whence comes the intelligence of the first cognitions man does not know, nor whence the affection for the first objects of desire, which exist in you even as zeal in the bee for making honey; and this primal will admits no deserving of praise or blame. Now in order that to this will every other will may be conformed, there is innate in you the faculty that counsels and that ought to hold the threshold of consent. This is the principle wherefrom is derived the reason of desert in you, according as it garners and winnows good and evil loves. Those who in their reasoning went to the root of the matter took note of this innate liberty, and accordingly bequeathed ethics to the world." Thomas on natural and elective love (jilectio naturalio and dilectio electiva), ST Ia.60.2 resp.: in Angelis est quaedam dilectio naturalis et quaedam electiva. Et naturalis dilectio in eis est principium electivae, quia semper id quod pertinet ad prius, habet rationem principii; unde, cum natura sit primum quod est in unoquoque, oportet quod id quod ad naturam pertinet, sit principium in quolibet. Et hoc apparet in homine et quantum ad intellectum, et quantum ad voluntatem. Intellectus enim cognoscit principia naturaliter, et ex hac cognitione causatur in homine scientia conclusionum, quae non cognoscuntur naturaliter ab homine, sed per inventionem vel doctrinam. Similiter in voluntate finis hoc modo se habet, sicut principium in intellectu, ut dicitur in II Physic. Unde voluntas naturaliter tendit in suum finem ultimum, omnis enim homo naturaliter vult beatitudinem. Et ex hac naturali voluntate causantur omnes aliae voluntates, cum quidquid homo vult, velit propter finem. Dilectio igitur boni quod homo naturaliter vult sicut finem, est dilectio naturalis, dilectio autem ab hac derivata, quae est boni quod diligitur propter finem, est dilectio electiva.' O. Ciacci, 'La teoria dell'amore: Canto XVII del Purgatorio', in Nuove interpretazioni dantesche (Perugia: Volumina, 1974), pp. 75-95; K. Foster, O.P., 'The Human Spirit in Action: Purgatorio XVIII', in The Two Dantes (London: Darton, Longman and Todd, 1977), pp. 107-119; B. Nardi, 'Filosofia dell'amore nei rimatori italiani del Duecento e in Dante', in Dante e la cultura medievale, ed. P. Mazzantini (Bari: Laterza, 1983, originally 1942), pp. 9-79; G. Morgan, 'Natural and Spiritual Movements of Love in the Soul: an Explanation of Purgatorio XVIII. 16-39', Modern Language Review 80 (1985), 2, 320-29; S. F. Di Zenzo, 'La dottrina dell'amore nel Purgatorio dantesco', Avallon 18 (1988), 99-114; C. Fordyce, 'Il 
Man as man, Dante suggests, knows himself in two kinds of loving. He knows himself in the kind of connatural loving given with the act itself of existence and calling him from beforehand into the presence of God as the first and final cause of all loving ('amore naturale'), and he knows himself in the kind of contingent loving generated by his encounter with the world around him ('amore d'animo'), his task as a creature of moral accountability being to gather in the latter to the former as the principle of his proper well-being, this gathering in of the one to the other being the province of free will, of that faculty of the rational soul empowered to decisive intervention. Only in the degree to which he is successful in this, in bringing home occasional to essential loving, will he know himself in the integrity and intelligibility of his presence in the world and in his acceptability in the sight of God. Short of this, he knows himself, and is known to his maker, only under the aspect of effrontery. But that is not all, for in the moment of his disinclination to bring home one species of loving to another, the next man, inasmuch as he is known to him at all, is known to him by way only of intimidation, as forever looking to see him off as a competitor and an intruder, at which point the social aspect of it all - sin under the aspect of savagery - moves into view; so, for example, the cases of the avaricious and of the prodigal in Canto VII of the Inferno and of the counterfeiters in Canto XXX, each of whom, divided against self in the recesses of self, lives at enmity with the world beyond self, the crisis of collectivity being in this sense nothing but the crisis of personality writ large:

Qui vid' i' gente più ch'altrove troppa, e d'una parte e d'altra, con grand' urli, voltando pesi per forza di poppa.

Percotëansi 'ncontro; e poscia pur lì si rivolgea ciascun, voltando a retro, gridando: "Perché tieni?" e "Perché burli?" ...

E l'un di lor, che si recò a noia forse d'esser nomato sì oscuro, col pugno li percosse l'epa croia.

Quella sonò come fosse un tamburo; e mastro Adamo li percosse il volto

problema di amore e libero arbitrio nella Commedia di Dante', Romance Review 4 (1994), 1, 35-51; S. Wenzel, 'Dante's Rationale for the Seven Deadly Sins (Purgatorio XVII)' in Dante. The Critical Complex, 8 vols, ed. R. Lansing (New York and London, 2003), vol. 3, pp. 227-31 (and in Elucidations. Medieval Poetry and its Religious Backgrounds (Louvain and Paris: Walpole and Peeters, 2010), pp. 113-19; originally 1965). 
col braccio suo, che non parve men duro,

dicendo a lui: "Ancor che mi sia tolto

lo muover per le membra che son gravi,

ho io il braccio a tal mestiere sciolto"

(Inf. VII.26-30 and XXX.100-108) ${ }^{8}$

Both psychologically and socially, then, it is a question of hostility. Ranged over against self in the forum of conscience and forever living out the fragility of this situation, the individual impressed by a sense of his vulnerability in the world only ever knows his neighbour in a spirit of resentment, of, at best, inconvenience and, at worst, menace, herein, in the a-sociology of the Inferno, in its sense of being as but a matter of overagainstness, lying the twofold substance and sadness of it all.

4. What, then, of being in its authenticity, of being as gathered on the plane of loving? In circumstances of inauthentic being communication gives way as we have seen to communicationlessness. Established at the centre of his universe, the individual neither knows nor is known by the next man, preferring instead to subsist as a stranger to every kind of creative communion. But in circumstances of authentic being, of being as transparent to its own innermost reasons, a new species of collectivity emerges, repudiation giving way to recognition as a habit of mind, to a sense of the next man as present to self, less as an impediment, than as a means of affirmation. To take, then, the Pauline model of contiguity, of being as a matter of being alongside, we have first of all the Charles Martel passage of Paradiso VIII, a passage for all its soaring substance alert to the notion of being and becoming in man as a matter of civic being and becoming, of the individual's bringing what he is and what he has by way of the unprecedented and unparalleled properties of personality to the collective enterprise:

Ond' elli ancora: "Or dì: sarebbe il peggio

per l'omo in terra, se non fosse cive?".

"Sì”, rispuos' io; "e qui ragion non cheggio".

"E puot' elli esser, se giù non si vive

diversamente per diversi offici?

${ }^{8}$ Here I saw far more people than elsewhere, both on the one side and on the other, howling loudly, rolling weights, which they pushed with their chest; they clashed together, and then right there each wheeled round, rolling back his weight, shouting, "Why do you hoard?" and "Why do you squander?" ... And one of them, who took offence perhaps at being named so darkly, with his fist struck him on his stiff paunch; it sounded like a drum; and Master Adam struck him in the face with his arm, which seemed no less hard, saying to him, "Though I am kept from moving by the weight of my limbs, which are heavy, I have a free arm for such a need". 
Non, se 'l maestro vostro ben vi scrive".

Sì venne deducendo infino a quici;

poscia conchiuse: "Dunque esser diverse

convien di vostri effetti le radici:

per ch'un nasce Solone e altro Serse,

altro Melchisedèch e altro quello

che, volando per l'aere, il figlio perse.

La circular natura, ch'è suggello

a la cera mortal, fa ben sua arte,

ma non distingue l'un da l'altro ostello.

Quinci addivien ch'Esaù si diparte

per seme da Iacòb; e vien Quirino

da sì vil padre, che si rende a Marte.

Natura generata il suo cammino

simil farebbe sempre a' generanti,

se non vincesse il proveder divino.

Or quel che t'era dietro t'è davanti:

ma perché sappi che di te mi giova, un corollario voglio che t'ammanti.

Sempre natura, se fortuna trova

discorde a sé, com' ogne altra semente

fuor di sua regïon, fa mala prova.

E se 'l mondo là giù ponesse mente

al fondamento che natura pone,

seguendo lui, avria buona la gente.

Ma voi torcete a la religïone

tal che fia nato a cignersi la spada,

e fate re di tal ch'è da sermone;

onde la traccia vostra è fuor di strada".

(Par. VIII.115-48) ${ }^{9}$

9 Whereupon he again, "Now say, would it be worse for man on earth if he were not a citizen?" "Yes", I replied, "and here I ask for no proof". "And can it be that, unless men below live in diverse ways for diverse duties? Not if your master writes well of this for you." Thus he came deducing far as here, then he concluded, "Therefore the roots of your works must be diverse, so that one is born of Solon and another Xerxes, one Melchizidek and another he who flew through the air and lost his son. Circling nature, which is a seal on mortal wax, performs its arts well, but does not distinguish one house from another. Whence it happens that Esau differs in the seed from Jacob, and Quirinus comes from so base a father that he is ascribed to Mars. The begotten nature would always make its course like its begetters did not divine provision overrule. Now that which was behind you is before you; but, that you may know that I delight in you, I will have a corollary cloak you round. Ever does Nature, if she find fortune discordant with herself, like any kind of seed out of its proper region, come to ill result. And if the word there below would give heed to the foundation which Nature lays, and followed it, it would have 
Eloquent as this is, however, in respect of alongsidedness as a model of collective being, it is only with Thomas, a little further down the line, that we glimpse something of its refined and indeed rapturous substance; for with Thomas it is a question, not simply of citizenship, but of companionship, of a species of co-presencing apt by way of those same properties of personality to confirm each alike in a sense of the fullness and incontrovertibility of his own presence in the world, in the deep substance of his own humanity:

Tu vuo' saper di quai piante s'infiora questa ghirlanda che 'ntorno vagheggia la bella donna ch'al ciel t'avvalora.

Io fui de li agni de la santa greggia che Domenico mena per cammino u' ben s'impingua se non si vaneggia.

Questi che m'è a destra più vicino, frate e maestro fummi, ed esso Alberto è di Cologna, e io Thomas d'Aquino.

Se sì di tutti li altri esser vuo' certo, di retro al mio parlar ten vien col viso girando su per lo beato serto.

Quell' altro fiammeggiare esce del riso di Grazïan, che l'uno e l'altro foro aiutò sì che piace in paradiso.

L'altro ch'appresso addorna il nostro coro, quel Pietro fu che con la poverella offerse a Santa Chiesa suo tesoro.

La quinta luce, ch'è tra noi più bella, spira di tale amor, che tutto 'l mondo là giù ne gola di saper novella: entro v'è l'alta mente u' sì profondo saver fu messo, che, se 'l vero è vero, a veder tanto non surse il secondo.

Appresso vedi il lume di quel cero che giù in carne più a dentro vide l'angelica natura e 'l ministero.

Ne l'altra piccioletta luce ride

its people good. But you wrest to religion one born to girt on the sword, and you make a king one that is fit for sermons, so that your track is off the road". On the specificity, well-nigh, of this or that instance of properly human being in its historical instantiation, DVE I.iii.1: 'Cum igitur homo non nature instinctu, sed ratione moveatur, et ipsa ratio vel circa discretionem vel circa iudicium vel circa electionem diversificetur in singulis, adeo ut fere quilibet sua propria specie videatur gaudere, per proprios actus vel passiones, ut brutum anirnal, neminem alium intelligere opinamur.' 
quello avvocato de' tempi cristiani del cui latino Augustin si provide.

Or se tu l'occhio de la mente trani

di luce in luce dietro a le mie lode, già de l'ottava con sete rimani.

Per vedere ogne ben dentro vi gode

l'anima santa che 'l mondo fallace

fa manifesto a chi di lei ben ode.

Lo corpo ond' ella fu cacciata giace

giuso in Cieldauro; ed essa da martiro

e da essilio venne a questa pace.

Vedi oltre fiammeggiar l'ardente spiro

d'Isidoro, di Beda e di Riccardo,

che a considerar fu più che viro.

Questi onde a me ritorna il tuo riguardo,

è 'l lume d'uno spirto che 'n pensieri

gravi a morir li parve venir tardo:

essa è la luce etterna di Sigieri,

che, leggendo nel Vico de li Strami,

silogizzò invidïosi veri.

(Par. X.91-138) $)^{10}$

Here, then, patient demonstration (the 'Sì venne deducendo infino a quici' of VIII.121) gives way to something closer to concelebration as a

${ }^{10}$ You wish to know what plants these are that enflower this garland, which amorously circles round the fair lady who strengthens you for heaven. I was of the lambs of the holy flock which Dominic leads on the path where there is good fattening if they do not stray. He that is next beside on the right was my brother and my master, and he is Albert of Cologne, and I, Thomas of Aquino. If thus of all the rest you would be informed, come, following my speech with your sight. The next flaming comes from the smile of Gratian, who served the one and the other court so well that it pleases in paradise. The other who next adorns our choir was that Peter who, like the poor widow, offered his treasure to Holy Church. The fifth light, which is the most beautiful among us, breathes with such love that all the world there below thirsts to know tidings of it. Within it is the lofty mind to which was given wisdom so deep that, if the truth be true, there never rose a second of such full vision. At its side behold the light of that candle which, below in the flesh, saw deepest into the angelic nature and its ministry. In the next little light smiles that defender of the Christian times of whose discourse Augustine made use. If now you are bringing your mind's eye from light to light after my praises, you are already thirsting for the eighth. Therewithin, through seeing every good, the sainted soul rejoices who makes the fallacious world manifest to any who listen well to him. The body from which it was driven lies down below in Cieldauro, and he came from martyrdom and exile to this peace. See, flaming beyond, the glowing breath of Isidore, of Bede, and of Richard who in contemplation was more than man. This one from whom your look returns to me is the light of a spirit to whom, in his grave thoughts, it seemed that death came slow. It is the eternal light of Siger who, lecturing in Straw Street, demonstrated invidious truths. 
mode of existence, Thomas's, whatever else it is, being an ode to friendship as the way of properly human affirmation. Fully and unambiguously himself, in other words, and operating from out of a space wholly his own, one individual comes alongside another to reassure him in respect both of the distinctiveness and the decisiveness of his presence - of the presence of each alike - in the world as party to the common undertaking and the universal hymn of praise.

But that is not all, for the argument stands now to be developed in terms of the way in which, operating as it does from out of his own space, each of those party to the universal proclamation may be said to operate from out of the same space, from out of a consummate act of indwelling. The model is Trinitarian, Dante's Trinitarianism having about it both a processional and a perichoretic aspect. First, then, on the processional side, there is his sense of the Son's issuing from the Father by way of filiation or of begottenness, and of the Spirit's issuing from the Father and the Son together by way of spiration or of a species of breathing-forth; so, for example, these two passages from Paradiso X (lines 1-6 and 49-51), the former, in its attentiveness to the filioque (to the doctrine of the Spirit's proceeding from both the Father and the Son), recalling the Augustine of the De trinitate, and the latter, more attuned to issues of filiation and spiration, the Thomas of the Summa theologiae:

Guardando nel suo Figlio con l'Amore che l'uno e l'altro etternalmente spira, lo primo e ineffabile Valore

quanto per mente e per loco si gira con tant' ordine fé, ch'esser non puote sanza gustar di lui chi ciò rimira.

...

Tal era quivi la quarta famiglia de l'alto Padre, che sempre la sazia, mostrando come spira e come figlia. ${ }^{11}$

${ }^{11}$ Looking upon his Son with the love which the one and the other eternally breathe forth, the primal and ineffable power made everything that revolves through the mind or through space with such order that he who contemplates it cannot but taste of him ... Such was here the fourth family of the exalted Father who ever satisfies it, showing how he breathes forth and how he begets.

Most recently on the filioque (Augustine, De trin. XV.v.29; 45; Anselm, Pros. xxiii, etc.), A. Riaud, Le Filioque: origine et rôle de la troisième personne de la Trinité (Paris: Fraternités du Saint-Esprit, 1989); R. Simon, Das Filioque bei Thomas von Aquin: eine Untersuchung zur Jogmengeschichtlichen Stellung, theologischen Struktur und ökumenischen Perspektive Jer thomanischen Gotteslebre (Frankfurt am Main and New York: P. Lang, 1994); P. Gemeinhardt, Die Filioque-Kontroverse zwischen Ost-und Westkirche im Frühmittelalter (Berlin and New York: Walter de Gruyter, 2002); D. Ngien, Apologetic for Filioque in Medieval 
On the perichoretic side, by contrast, there his sense of the mutual indwelling or 'inseatedness' of the three Persons of the Trinity, a model open to contemplation under the aspect, less now of extensivity, than of intensivity or co-dimensionality; ${ }^{12}$ so, for example, again from the Paradiso,

Theology (Bletchley and Waynesboro, GA: Paternoster, 2005). Thomas on filiation and spiration, ST Ia.28.4 resp.: 'Processio autem verbi dicitur generatio secundum propriam rationem qua competit rebus viventibus. Relatio autem principii generationis in viventibus perfectis dicitur paternitas; relatio vero procedentis a principio dicitur filiatio. Processio vero amoris non habet nomen proprium ... Sed vocatur relatio principii hujus processionis spiratio.' On the procession of the Spirit from the Father by way of the Son, ST Ia.36. $2-3$, and on the procession of the Spirit from the Son, $S c G$ IV.xxiv-xxv. Notable among the finer points of Dantean Trinitarianism are (a) its appropriation of creative power in the Par. X.1-6 passage to the Father (the 'con tant' ordine fé' of line 5; cf. Thomas, ST Ia.45.6 ad 2: 'patri attribuitur et appropriatur potentia, quae maxime manifestatur in creatione; et ideo attribuitur patri creatorem esse. Filio autem appropriatur sapientia, per quam agens per intellectum operatur, et ideo dicitur de Filio per quem omnia facta sunt. Spiritui Sancto autem appropriatur bonitas, ad quam pertinet gubernatio, deducens res in debitos fines, et vivificatio'); (b) its sense of the dispositive role of the Spirit in respect of the Word as a principle of creation (the 'Però se 'l caldo amor la chiara vista / de la prima virtù dispone e segna, / tutta la perfezione quivi s'acquista' of Par. XIII.7981); and (c) its linking of divine subsistence with the splendour of the Son in particular (the Idea or $\lambda$ ógos) as the in-and-through-which of the creative initiative (the 'Ciò che non more e ciò che può morire / non è se non splendor di quella idea / che partorisce, amando, il nostro Sire' of Par. XIII.52-54, for which the 'Qui cum sit splendor gloriae, et figura substantiae ejus, portansque omnia verbo virtutis suae' of Heb. 1:3). In respect of the first and third of these emphases, Thomas, $S T$ Ia. 46.3 resp.: 'Sicut enim principium effectivum appropriatur patri, propter potentiam, ita principium exemplare appropriatur filio, propter sapientiam, ut sicut dicitur, omnia in sapientia fecisti, ita intelligatur Deum omnia fecisse in principio, idest in filio; secundum illud apostoli ad Coloss. I, in ipso, scilicet filio, condita sunt universa.'

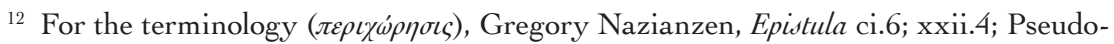
Cyril, De sacro. trin. xxiv; John of Damascus De fide ortho. i.14, etc. On the notion of perichoresis as dance (a pseudo-etymology), Hilary, De trin. ix.69. Historically and dogmatically, A. Deneffe, 'Perichoresis, circumincessio, circuminsessio,' in Zeitschrift für katholische Theologie 47 (1923), 497-532; D. F. Stramara Jr, 'Gregory of Nyssa's Terminology for Trinitarian Perichoresis', Vigiliae Christianae 52 (1998), 3, 257-63; R. Cross, 'Perichoresis, Deification, and Christological Predication in John of Damascus', Medieval Studies 62 (2000), 69-124. For an up-to-date implementation of the idea, E. L. Simmons, 'Quantum Perichoresis: Quantum Field Theory and the Trinity', Theology and Science 4 (2006), 2, 137-50. As part of a more general synthesis, J. Macquarrie, Principles of Christian Theology, rev. edn (London: SCM Press, 1966), pp. 174ff.; J. N. D. Kelly, Early Christian Doctrines, 5th edn (London: Adam and Charles Black, 1977), pp. 263ff.; T. F. Torrance, The Trinitarian Faith: The Evangelical Theology of the Ancient Catholic Church (Edinburgh: T. \& T. Clark, 1988); idem, Trinitarian Perspectives: Towards Doctrinal Agreement (Edinburgh: T. \& T. Clark, 1994), especially pp. 32-33, 93ff. and 121-23; C. Gunton, The Promise of Trinitarian Theology, 2nd edn (Edinburgh: T. \& T. Clark, 1997); P. S. Fiddes, Participating in God: A Pastoral Doctrine of the Trinity (London: Darton, Longman and Todd, 2000), pp. $71 \mathrm{ff}$. More generally still on Trinitarian theology, E. J. Fortman, The Triune God: A Historical Study of the Doctrine of the Trinity (London: Hutchinson, 1972); D. Brown, 
these passages from Cantos XXIV and XXXIII (139-41 and 124-26 respectively), the first a meditation on the grammar of Trinitarianism, and the second on the notion of inseatedness (the 'in te sidi' of XXXIII.124) and on this as a matter of love and laughter:

e credo in tre persone etterne, e queste credo una essenza sì una e sì trina, che soffera congiunto 'sono' ed 'este'. ...

O luce etterna che sola in te sidi, sola t'intendi, e da te intelletta e intendente te ami e arridi $!^{13}$

Dante's, then, to go by the rapt emphases of Paradiso XXXIII, is a privileging of essence over economy as a way of seeing and celebrating the three-in-oneness of the Godhead, this in turn encouraging him in the most resplendent of his social formulations in the Commedia, in what amounts to his last word on the nature of one man's being with another at the point of emergence; for to be with the next man at the point of emergence is to be, not so much with him, as within him, as, somewhat after the manner of the Persons themselves of the Godhead, indwelling and indwelt one by the other. This at any rate is the implication, indeed the substance, of Dante's initiative in the ninth canto of the Paradiso when, proceeding once again neologistically

The Divine Trinity (London: Duckworth, 1985), especially pp. $272 \mathrm{ff}$.

Otherwise on the Trinity in Dante: Inf. III.4-6: 'Giustizia mosse il mio alto fattore; / fecemi la divina podestate, / la somma sapienza e 'l primo amore', with reference to the opus ad extra of the Trinity as a principle of cosmic organization; Par. XXXIII.115-20: 'Ne la profonda e chiara sussistenza / de l'alto lume parvermi tre giri / di tre colori e d'una contenenza; / e l'un da l'altro come iri da iri / parea reflesso, e 'l terzo parea foco / che quinci e quindi igualmente si spiri', with reference to the annular imagery of, especially, Joachim of Fiore (L. Tondelli (ed.), Il libro delle figure dell'abate Gioachino da Fiore, 2nd edn (Turin: Società editrice internazionale, 1990)). G. Busnelli, 'Dalla luce del cielo della luna alla trina luce dell’Empireo', Studidanteschi 27 (1943), 95-116; M. Apollonio, 'Una meditazione trinitaria', in Dante. Storia della Commedia (Milan: Vallardi, 1951), pp. 182-90; G. Fallani, Dante poeta teologo (Milan: Marzorati, 1965), pp. 211-25; idem, ad voc. 'Trinità', in the Enciclopedia Jantesca, 6 vols (Rome: Istituto della Enciclopedia Italiana, 1970-78), vol. 5, pp. 718-21; P. Priest, Dante's Incarnation of the Trinity (Ravenna: Longo, 1982); V. Crupi, 'Dal Paradiso di Dante: l'impronta trinitaria nella creazione', Nuova Umanità 13536 (2001), 433-63 (subsequently in Saggi danteschi (Cosenza: Luigi Pellegrini, 2003), pp. 33-68, with 'La Trinità nell'esegesi dantesca' in the same volume, pp. 69-105); G. Montanari, 'Terza parte; saggio teologico. Una terzina da rivedere: Par. XXXIII, 124126 sulla Trinità?', in Socrate, Cristo, Dante e la Bibbia: saggi di filologia estetica e sull'ebraismo fondamento della cultura (Ravenna: Girasole, 2002), pp. 93-123.

${ }_{13}$ And I believe in three eternal persons, and these I believe to be one essence, so one and so threefold as to comport at once with are and is ... O light eternal, who alone abidest in thyself, and, known to thyself and knowing, lovest and smilest on thyself! 
(the 'com' a lo re che 'n suo voler ne 'nvoglia' of Par. III.84 or the 'D'i Serafin che più s'india' of IV.28), he speaks of the kind of 'inhimming', 'inyouing' and 'inmeing' whereby one instance of being in its blessedness may be said to indwell another, a way of thinking and of speaking designed, not so much to liquidate otherness as a property of historical selfhood, as to confirm the radical nature of one man's presence to another in the moment of selfactualization. In the moment of self-actualization, Dante maintains, one man is present to another, not merely as a companion or fellow breaker of bread, but as an immanently operative principle of being and becoming, at which point diversity gives way to identity as a principle of social intelligence, as a way of conceiving and articulating the dialectic in human experience of being in self and being with another, of Selbstsein and Mitsein:

"Dio vede tutto, e tuo veder s'inluia", diss' io, "beato spirto, sì che nulla voglia di sé a te puot' esser fuia.

Dunque la voce tua, che 'l ciel trastulla sempre col canto di quei fuochi pii che di sei ali facen la coculla, perché non satisface a' miei disii? Già non attendere' io tua dimanda, s'io m'intuassi, come tu t'inmii".

$(\text { Par. IX.73-81) })^{14}$

Thus Trinitarianism once again encourages and facilitates, as Trinitarianism always, does a rethinking of the social issue in human experience; for if on the one hand there is a sense in which to be as man is to stand alone in respect of that which matters alone (this being the point of Dante's preference for the first-person singular in the Commedia), there is also a sense in which that same being both knows and is known by way of its brooking no dimensionality, no impediment to the mutual informing of self and the other-than-self in the moment of affirmation.

14 "God sees all, and into him your vision sinks, blessed spirit", I said, "so that no wish may steal itself from you. Why then does your voice, which ever gladdens heaven - together with the singing of those devout fires that make themselves a cowl with six wings - not satisfy my longings? Surely I should not wait for your request, were I in you, even as you are in me”. Cf. Par. XXII.124-29: “'Tu se' sì presso a l'ultima salute”, / cominciò Bëatrice, "che tu dei / aver le luci tue chiare e acute; / e però, prima che tu più t'inlei, / rimira in giù, e vedi quanto mondo / sotto li piedi già esser ti fei”. 